ISSN 1678-3921

Journal homepage: www.embrapa.br/pab

For manuscript submission and journal contents, access: www.scielo.br/pab

\author{
Valéria Aparecida Vieira Queiroz ${ }^{(1 凶)(i D,}$ \\ Vinícius Tadeu da Veiga Correia(2) (D), \\ Cícero Beserra de Menezes(1) (iD, \\ Rafael de Araújo Miguel(1) (iD, \\ Renata Regina Pereira da Conceição(2) (iD, \\ Caroline Liboreiro Paiva ${ }^{(3)}$ (ID) and \\ José Edson Fontes Figueiredo(1) (iD \\ (1) Embrapa Milho e Sorgo, Rodovia MG-424, \\ Km 45, CEP 35702-098 Sete Lagoas, MG \\ Brazil. \\ E-mail: valeria.vieira@embrapa.br, \\ cicero.menezes@embrapa.br, \\ rafael.miguel@embrapa.br. \\ jose.edson@embrapa.br \\ (2) Universidade Federal de Minas Gerais, \\ Avenida Antônio Carlos, № 6.627, \\ CEP 31270-901 Belo Horizonte, MG, Brazil. \\ E-mail: viniciustadeu18@hotmail.com, \\ renataponts@gmail.com \\ (3) Universidade Federal de Minas Gerais, \\ Instituto de Ciências Agrárias, Avenida \\ Universitária, № 1.000, CEP 39404-547 \\ Montes Claros, MG, Brazil. \\ E-mail: carolinepaiva7@gmail.com \\ $\bowtie$ Corresponding author
}

Received

April 02, 2020

Accepted

October 30, 2020

How to cite

QUEIROZ, V.A.V.; CORREIA, V.T. da V.; MENEZES, C.B. de; MIGUEL, R. de A.; CONCEICCÃO, R.R.P. da; PAIVA, C.L.; FIGUEIREDO, J.E.F. Retention of phenolic compounds and acceptability of gluten-free churros made with tannin or tannin-free sorghum flour. Pesquisa Agropecuária Brasileira, v.55, e02288, 2020. DOI: https://doi. org/10.1590/S1678-3921. pab2020.v55.02288.

\section{Retention of phenolic compounds and acceptability of gluten-free churros made with tannin or tannin-free sorghum flour}

\begin{abstract}
The objective of this work was to evaluate the acceptability of gluten-free churros made either with tannin or tannin-free sorghum flour, as well as the retention of their phenolic compounds and antioxidant capacity retention after cooking and frying. The churros were developed by replacing wheat flour with sorghum flour from the sorghum cultivars BRS 305 with tannin (T-churro) or BRS 501 tannin free (TF-churro). The content of phenolic compounds and antioxidant activity were evaluated before and after the thermal processing. Both products had a high acceptability $(84.5-95.5 \%)$ for all evaluated sensory attributes, and no difference was observed for color, aroma, and flavor. However, the T-churro showed a higher acceptance for texture, overall acceptability, and purchase intention. The churros had a similar proximate composition for fiber content. The phenol content was about three times and antioxidant activity about 20 times higher for T-churro than for TFchurro. Although subjected to two types of processing (cooking and frying), the fried and ready-to-eat T-churro retained more than $50 \%$ of anthocyanins, phenols, and antioxidant activity. The TF-churro product showed a retention of these compounds above 70,40 , and $65 \%$, respectively. The tannin content of 'BRS 305' sorghum increases its functional potential and does not negatively affect the acceptability of the churros. Sorghum either with or without tannins has the potential to be used for the production of gluten-free churros.
\end{abstract}

Index terms: Sorghum bicolor, bioactive compounds, gluten-free food, sorghum product.

\section{Retenção de compostos fenólicos e aceitabilidade de churros sem glúten feitos com farinha de sorgo com ou sem tanino}

Resumo - O objetivo deste trabalho foi avaliar a aceitabilidade de churros sem glúten, feitos com farinha de sorgo com ou sem tanino, assim como a retenção de seus compostos fenólicos e da sua capacidade antioxidante após processamento por cozimento e fritura. Os churros foram desenvolvidos pela substituição da farinha de trigo por farinhas de sorgo das cultivares BRS 305 com tanino (T-churro) ou BR 501 sem tanino (TF-churro). O teor de compostos fenólicos e a atividade antioxidante foram avaliados antes e depois do processamento térmico. Ambos os produtos apresentaram alta aceitabilidade $(84,5-95,5 \%)$ para todos os atributos sensoriais avaliados, e nenhuma diferença foi observada quanto à cor, ao aroma e ao sabor. Entretanto, o T-churro teve maior aceitação quanto à textura, à aceitabilidade geral e à intenção de compra. Os churros apresentaram composição centesimal semelhante quanto ao conteúdo de fibra. O teor de fenol foi cerca de três vezes e a atividade antioxidante cerca de 20 vezes maior no T-churro do que 
no TF-churro. Apesar de ter sido submetido a dois tipos de processamento (cozimento e fritura), o T-churro frito pronto para consumo apresentou mais de $50 \%$ de retenção de antocianinas, fenóis e atividade antioxidante, após a fritura. $\mathrm{O}$ produto $\mathrm{TF}$-churro apresentou retenção desses compostos acima de 70,40 e $65 \%$, respectivamente. $\mathrm{O}$ teor de tanino do sorgo 'BRS 305' aumenta seu potencial funcional e não afeta negativamente a aceitabilidade dos churros. Sorgos com ou sem taninos têm potencial para a produção de churros sem glúten.

Termos para indexação: Sorghum bicolor, compostos bioativos, alimentos sem glúten, produtos de sorgo.

\section{Introduction}

The interest in healthy food and economically viable food production has increased considerably in recent years. In this context, sorghum has been highlighted as a good option because of its higher tolerance to drought and lower costs of production in comparison with other cereals (Queiroz et al., 2015). Some sorghum genotypes are sources of fibers, minerals, vitamin E, and bioactive compounds, such as anthocyanins, tannins, phenolic acids, resistant starch, and other compounds that are beneficial to human health (Martino et al., 2012; Cardoso et al., 2017). Furthermore, sorghum is a potential ingredient for safe gluten-free food (Queiroz et al., 2012), whose demand is rising exponentially due to the increasing cases of sensitivity to gluten (Queiroz et al., 2012, 2018; Anunciação et al., 2017). In recent years, many studies have been done for developing gluten-free products using naturally gluten-free flour from different plant species, including sorghum (Adiamo et al., 2018).

In Brazil, although the cultivation of sorghum is destined almost exclusively for animal feed, its use as human food has a great potential for the local market (Anunciação et al., 2017). Some products like cereal bars (Queiroz et al., 2012), cookies (Soares et al., 2019), breakfast cereals (Anunciação et al., 2017), beverages (Queiroz et al., 2018), and others, have been developed and showed good sensory acceptance.

Sorghum tannins show anticarcinogenic and antimutagenic properties, which may be related to their antioxidant activity that is essential to protect cells against oxidative damages. Tannin sorghum has also been widely reported to reduce caloric availability and weight gain, thus becoming a consumer option for people with special diets for weight loss (Wu et al., 2012). Speculations have been arisen on these substances for the control of diabetes and obesity in humans (Cardoso et al., 2017). However, tannins are considered undesirable from the nutritional and sensory point of view, since these compounds can impart a residual astringent flavor to the products (Lesschaeve \& Noble, 2005). Thus, studies to evaluate the acceptability of sorghum processed food with or without tannins are of great importance, but they are still rare., more sensorial studies are necessary for the development of palatable gluten-free products based on sorghum, according to Chávez et al. (2018).

Sorghum is a rich source of phenolic compounds; however, the bioaccessibility to this source may be affected by processes applied during food processing, before consumption, which may interfere with their biological potential (Salazar-López et al., 2018). Studies evaluating the effect of different processing types on the nutritional, functional, and sensory qualities of sorghum products are necessary. For this purpose, several works have been conducted about the influence of boiling, cooking, soaking, dry heating, extrusion, fermentation, and other processes, especially for the phenolic compounds and antioxidant capacity, and showed different results (Salazar-López et al., 2018). However, we could not find reports on the effect of two types of processing (cooking and frying) on these characteristics in the same product.

Churros is a popular sweet snack in Latin America, usually prepared with wheat flour and water, in cylindrical format, fried in vegetable oil, and sprinkled or not with sugar, and cinnamon (Gomensoro, 1999). In some countries, churros are usually consumed without filling, but, in Brazil, the confection is typically stuffed with "doce de leite" (a sweet made with milk and sugar). Nevertheless, besides having few gluten-free versions, churro is subjected to two types of thermal processing that are cooking and frying, thus, it is an excellent product for the evaluation of the retention degree of biocompounds in the ready-to-eat form.

The objective of this work was to evaluate the acceptability of gluten-free churros made either with tannin or tannin-free sorghum flour, as well as the retention of their phenolic compounds and antioxidant capacity retention after cooking and frying. 


\section{Materials and Methods}

Tannin-free flour from the BR 501 sorghum cultivar, which is has white pericarp, and flour with tannin from BRS 305 sorghum cultivar, with brown pericarp (Martino et al., 2012) were used for churro manufacture.

The sorghum [Sorghum bicolor (L.) Moench] cultivars were planted and harvested under the same field conditions in the 2015/2016 crop season, in the experimental fields of Embrapa Milho e Sorgo, in the municipality of Sete Lagoas $\left(19^{\circ} 28^{\prime} \mathrm{S}, 4^{\circ} 15^{\prime} 08^{\prime \prime} \mathrm{W}\right.$, at an altitude of $732 \mathrm{~m}$ ), in the state of Minas Gerais, Brazil. After harvesting, whole sorghum grains were milled twice to obtain flour with $0.5 \mathrm{~mm}$ particle size, using a laboratory mill model HM-1 (Hawos, Bad Homburg vor der Höhe, Germany).

Two churro formulations were prepared, containing the following ingredients: whole sorghum flour $(200 \mathrm{~g}$, $36.4 \%$ ), water ( $250 \mathrm{~mL}, 45.5 \%)$, egg (50 g, 9.1\%), sugar (25 g, 4.5\%), butter ( $23 \mathrm{~g}, 4.2 \%$ ), and salt (1 g, $0.2 \%$ ). The products were differentiated according to the sorghum flour used: one product was made with the tannin-sorghum cultivar BRS 305 (T-churro) and the other was made with the tannin-free sorghum cultivar BR 501 (TF-churro). For the two formulations, the ingredients were blended and baked for $8 \mathrm{~min}$. After cooling for $30 \mathrm{~min}$, dough was molded with a manual molder for churros and fried in hot soybean oil for $90 \mathrm{~s}$

For the sensorial test, the churros were sprinkled with refined sugar and cinnamon and filled with a commercial brand "doce de leite" (about $5 \mathrm{~g}$ for each one). The sensory tests to evaluate the acceptance of the churros made with tannin-sorghum flour (from 'BRS 305') and tannin-free sorghum flour (from 'BR 501') were carried out in the Sensory Analysis Laboratory of Universidade Federal de São João del-Rei, in the municipality of Sete Lagoas, in the state of Minas Gerais, Brazil. Nontrained consumers (84 women, and 26 men, totaling 110 people), between 18 and 65 years of age, evaluated the sensory acceptability of the products. Most panelists (91\%) were between 18 and 25 of age. Consumers were requested to sign an informed consent form, according to the Guidelines and Norms for Research with Humans, Resolution 466/2012 of Conselho Nacional de Saúde (CNS) (Brasil, 2013), the National health council of Brazil. The Human Ethics Research Committee at Universidade Federal de Minas Gerais, Brazil, approved this study (No.
03591312.0.0000.5149). For the test, samples were randomly served under white light, in disposable white plastic plates coded with three-digit random numbers. Water was provided for mouth rinsing between samples. Consumers were requested to taste the products and evaluate the acceptability of each sample as to color, aroma, texture, flavor, and overall acceptability, using a $10 \mathrm{~cm}$ hybrid hedonic scale ranging from 0 (dislike extremely) to 10 (like extremely) (Villanueva et al., 2005). They were also asked to evaluate their purchase intention for the tested products, using a 5-point scale (1 for "I would certainly not buy"; and 5 for "I would certainly buy"). A positive purchase intention was calculated according to the percentage of panelists who attributed scores from 4 to 5 (Luna Pizarro et al., 2015). For the five sensorial attributes evaluated, the individuals who attributed scores to the two formulations were divided as follows: group 1, rejection, attributed scores were $<5.0$; group 2, indifference, scores 5.0 and 5.9; group 3 , acceptance, attributed scores were $\geq 6.0$. Gularte (2009) consider a formulation as accepted, when its acceptance percentage is equal to or greater than $70 \%$.

Chemical analyses of the churros were carried out at Embrapa Milho e Sorgo, with freeze-dried samples without the layer of sugar and cinnamon and the filling of "doce de leite". The samples of crude, cooked, and fried churros, without the cinnamon and sugar layer and "doce de leite", were lyophilized in a freeze-dryer (Liotop, model L101, São Carlos, SP, Brazil) for 24 hours and stored at $-18^{\circ} \mathrm{C}$ for chemical analysis.

The proximate composition of the fried churros (as it is usually consumed) was determined for better characterizing the products. Protein content was determined by the Dumas method using a nitrogen analyzer (Leco, model FP-528 St. Joseph, MI, USA), and the results were multiplied by the factor 6.25 . Fiber (FDN) was analyzed using the Ankom system (Ankom, model A200, Macedon, NY, USA) according Queiroz et al. (2015). Lipids were determined using a fat extractor (Ankom, model XT10, Macedon, NY, USA), following the AOCS protocol (AOCS, 2004). Ash content was determined according to the AOAC method (Horwitz, 2000) with calcination of organic matter in a muffle(Quimis, model Q318M24, São Paulo, SP, Brazil). The gravimetric method determined the moisture using a forced-air circulation oven at $105^{\circ} \mathrm{C}$, for 6 hours. The carbohydrate content was calculated 
by the equation: $[100$ - (moisture + protein + lipid + ash + fiber)]. The caloric value (energy) was calculated using the Atwater conversion factors: $9 \mathrm{kcal} \mathrm{g}^{-1}$ lipid, 4 $\mathrm{kcal} \mathrm{g}^{-1}$ carbohydrate, and $4 \mathrm{cal} \mathrm{g}^{-1}$ protein (FAO, 2003). All results were expressed on a dry matter basis.

Antioxidant activity, total anthocyanins, and phenolic compound contents were determined in triplicate for the two flour types and for raw, cooked, and fried churros of both tannin (T-churro) and tanninfree (TF-churro). All results were expressed on a dry matter basis.

For phenolic compounds extraction, $0.25 \mathrm{~g}$ of samples were extracted in $25 \mathrm{~mL} 1 \% \mathrm{HCl} /$ methanol (v/v), for two hours, in a shaker (Nova Ética, 109, São Paulo, SP, Brazil). All extracts were centrifuged at 2,012 $\mathrm{g}$ for $10 \mathrm{~min}$, in a EBA 200 centrifuge (Hettich, Beverly, MA, USA), then decanted and immediately analyzed. The antioxidant activity was determined by the assay, described by Awika et al. (2003), using 2,2'azinobis (3-ethylbenzothiazoline-6-sulfonate) radical cation (ABTS +), Trolox was used as a standard, and the results were expressed as micromoles of Trolox equivalent (TE) $\mathrm{g}^{-1}$ of fresh matter. The modified FolinCiocalteu method, according to Kaluza et al. (1980), was used to quantify the total phenolic compounds. The absorbance was read on a spectrophotometer (Hitachi U-1100 UV-Visible, Tokyo, Japan) at $600 \mathrm{~nm}$, and the results were expressed as milligram of gallic acid equivalent (GAE) $\mathrm{g}^{-1}$ of sample on a dry basis (db). Total anthocyanins were determined by the method detailed by Awika et al. (2004). The absorbance of the extract samples was read at $480 \mathrm{~nm}$, in a spectrophotometer (Hitachi U-1100 UV-Visible, Tokyo, Japan). Results were expressed as milligram of luteolinidin equivalent (LE) $\mathrm{g}^{-1}$ of sample on a dry basis (db). Condensed tannins were determined by the vanillin- $\mathrm{HCl}$ method described by Price et al. (1978). Absorbance was read at $500 \mathrm{~nm}$ in a spectrophotometer (Hitachi U-1100 UVVisible, Tokyo, Japan), and the results were calculated and expressed as milligram of catechin equivalent (CE) $\mathrm{g}^{-1}$ sample on a dry basis. The percentage of retention and loss of the total phenols, anthocyanins, tannins, and antioxidant activity of the churros was calculated according to the following equations: $\mathrm{R}=\mathrm{C} 1 \times 100 / \mathrm{C} 2$, and $\mathrm{L}=100-\mathrm{R}$, in which: $\mathrm{R}$ is the retention (\%), $\mathrm{C} 1$ and $\mathrm{C} 2$ are, respectively, the concentrations of the fried and raw samples; and $\mathrm{L}$ is the percentage of loss.
A completely randomized design was used, with 110 replicates for the sensory analysis, represented by the tasters, and three replicates for the chemical analysis. Data were subjected to the analyses of variance, and the means were compared by the F-test (functional analysis), and by Tukey's test (sensory and chemistry analyses), at 5\% probability, using the Sisvar statistical program (Ferreira, 2011).

\section{Results and Discussion}

According to the sensory analysis, both churros formulations, elaborated with the sorghum cultivars BR 501 - with white pericarp and without tanin (TFchurro) - and BRS 305 - with brown pericarp and tanin (T-churro) -, showed a high sensory acceptance, with averages for the attributes color, aroma, texture, and overall impression between 7.8 and 8.7 (TF-churro) and between 8.0 and 8.8 (T-churro) (Figure 1). There was no significant difference between the products for color, aroma, and flavor attributes. However, concerning texture and overall acceptability, T-churro (from 'BRS 305') had a higher mean than the TF-churro (from 'BR 501').

Considering purchase intention, T-churro ('BRS 305') had a higher mean than TF-churro ('BR 501') (Figure 1), which is similar to the results by Queiroz et al. (2018), who reported a higher purchase intention for a drink formulated with tannin-sorghum flour than another made with tannin-free sorghum flour. About 93\% panelists attributed scores from 4 to 5 ("would probably buy" and "certainly buy", respectively) to T-churro ('BRS 305'), and 85\% to TF-churro ('BR 501') (Figure 2). According to Luna Pizarro et al. (2015), both products had a positive purchase intention.

Both sorghum churros were acceptable (Table 1) by showing a high acceptance index for all sensory attributes between 84.5 and $95.5 \%$, which is greater than the $70 \%$ that is the minimum for a product to be considered acceptably, according to Gularte (2009). The sensory analysis results showed that the high tannin content and brown-colored flour of 'BRS 305' did not negatively influence the acceptance of the churros made with this hybrid flour. Probably, the tannin taste was not perceived, or may not have been objectionable by the panelists (Queiroz et al., 2018).

A drink made with tannin sorghum was well accepted as another made with tannin-free sorghum, 
both with acceptance ranging from 70.9 to $93.2 \%$ for all sensory attributes, according to Queiroz et al. (2018). A good sensory acceptance was reported for cookies and savory fried pies made with the same tannin-rich sorghum ('BRS 305') as used in the present study (Soares et al., 2019); these authors observed a significant increase of the sensory scores after the information on sorghum benefits was disclosed, and concluded that these gluten-free products, prepared with tannin sorghum flour, have a great commercial potential.

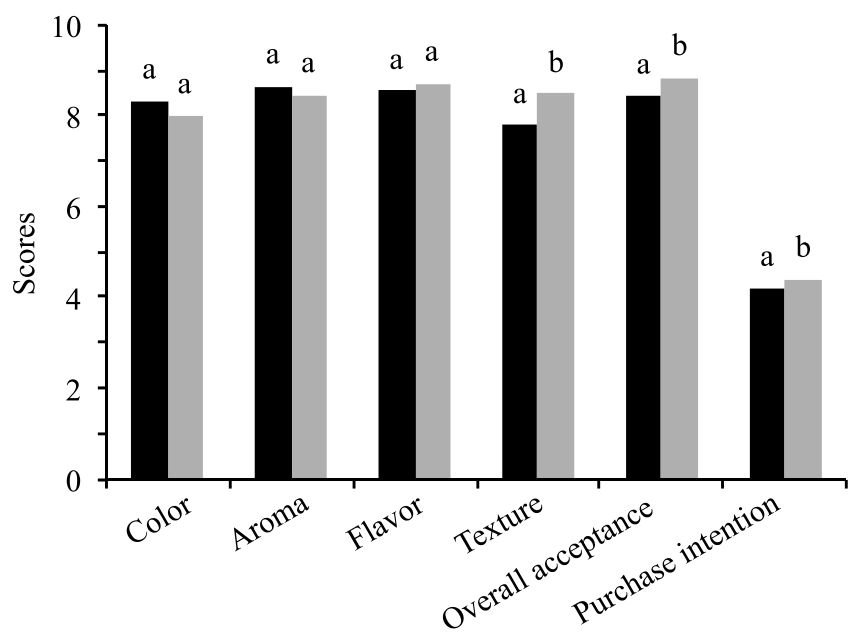

Sensory atributtes and purchase intention

$$
\text { - TF-churro T-churro }
$$

Figure 1. Scores (means) of sensory attributes and purchase intention for churros made with flour from the Sorghum bicolor cultivars BR 501 (tannin-free - TF-churro) and BRS 305 (with tannin - T-churro). Means followed by equal letters in the columns, for the same attribute, do not differ by the F-test, at $5 \%$ probability.
There were significant differences in the proximal composition between the two formulations (Table 2). Protein, fiber, and ash contents were high, and lipid carbohydrate contents and energy were lower in the formulation with the flour from 'BR 501' sorghum than that from 'BRS 305' sorghum. These differences may be attributed to variations in the chemical composition intrinsic to the two sorghum genotypes used. Although there were statistical differences for the levels of nutrients between the two products, as these were very small in absolute values, they probably will not impact the nutritional contribution of each one.

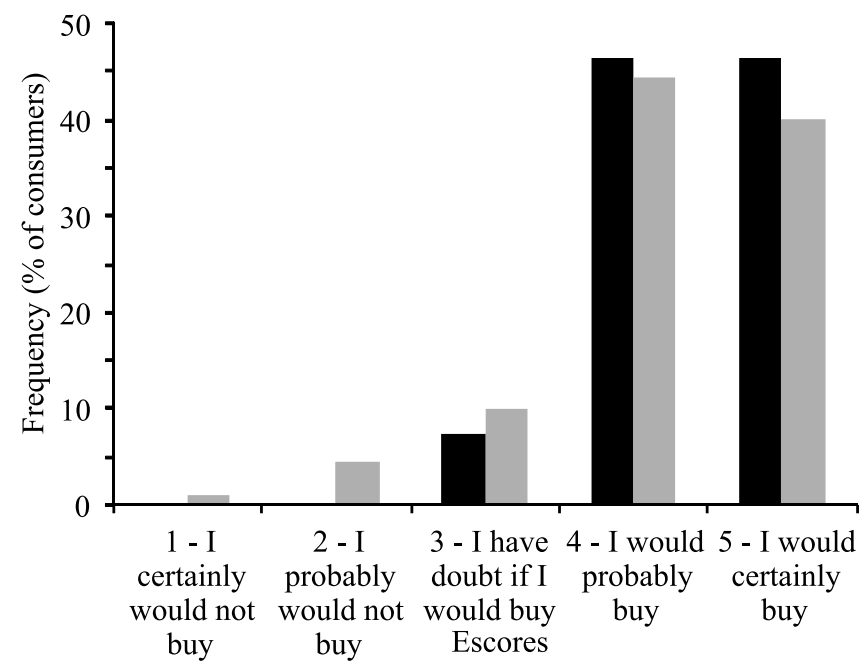

- T-churro TF-churro

Figure 2. Frequency of purchase intention scores for churros made with flour from the Sorghum bicolor cultivars BRS 305 (with tannin - T-churro) and BR 501 (tannin-free - TF-churro).

Table 1. Acceptability of churros prepared with flour from the Sorghum bicolor cultivars BRS 305 (with tannin - T-churro) and BR 501 (tannin-free - TF-churro).

\begin{tabular}{|c|c|c|c|c|c|c|c|}
\hline Formulation & Score & Acceptability $^{(1)}(\%)$ & Color & Aroma & Flavor & Texture & Overall acceptability \\
\hline \multirow{3}{*}{$\begin{array}{l}\text { T-churro } \\
\text { (BRS 305) }\end{array}$} & $\geq 6.0$ & Acceptance & 89.1 & 91.8 & 93.6 & 95.5 & 97.3 \\
\hline & $5.0-5.9$ & Indifference & 2.7 & 6.4 & 5.5 & 2.7 & 2.7 \\
\hline & $<5.0$ & Rejection & 8.2 & 1.8 & 0.9 & 1.8 & 0.0 \\
\hline \multirow{3}{*}{$\begin{array}{l}\text { TF-churro } \\
\text { (BR 501) }\end{array}$} & $\geq 6.0$ & Acceptance & 92.7 & 95.5 & 95.5 & 84.5 & 94.5 \\
\hline & $5.0-5.9$ & Indifference & 4.5 & 2.7 & 1.8 & 7.3 & 0.9 \\
\hline & $<5.0$ & Rejection & 2.7 & 1.8 & 2.7 & 8.2 & 4.5 \\
\hline
\end{tabular}

(1)Acceptabiliy: acceptance, percentage of individuals that attributed scores $\geq 6.0$; indifference, percentage of individuals that attributed scores between 5.0 and 5.9; rejection, percentage of individuals that attributed scores $<5.0$. 
T-churro and TF-churro made with 'BRS 305' tannin sorghum flour (T-churro) and 'BR 501' tannin-free sorghum flour (TF-churro) showed a better nutritional composition than two traditional commercial churros marketed in Brazil made with wheat flour (Loucos por Churros, 2018), which have only $6.2 \%$ protein and $1.2 \%$ fiber. Lipid content was similar between the sorghum churros (26.5-29\%) and the commercial churro (29.6\%). Considering a portion of $60 \mathrm{~g}$, both products can be considered with high fiber content (minimum $5 \mathrm{~g}$ of fiber per serving) (Anvisa, 2012). Queiroz et al. (2018) developed a powdered drink mix with tanninsorghum (PDT-3670) and tannin-free sorghum (PDTF-

Table 2. Proximate composition and energy (dry basis) in fried churros formulated with flour from the Sorghum bicolor cultivars BRS 305 (with tannin - T-churro) and BR 501 (tannin-free - TF-churro) $^{(1)}$.

\begin{tabular}{lcc}
\hline Nutrient & T-churro (BRS 305) & TF-churro (BRS 501) \\
\hline Protein (\%) & $9.56 \pm 0.26 \mathrm{~b}$ & $10.7 \pm 0.39 \mathrm{a}$ \\
Lipid (\%) & $29.0 \pm 0.72 \mathrm{a}$ & $26.5 \pm 0.17 \mathrm{~b}$ \\
Fiber (\%) & $25.0 \pm 1.22 \mathrm{~b}$ & $27.8 \pm 0.17 \mathrm{a}$ \\
Ash (\%) & $0.98 \pm 0.08 \mathrm{~b}$ & $1.21 \pm 0.03 \mathrm{a}$ \\
Carbohydrate (\%) & $35.5 \pm 0.51 \mathrm{a}$ & $33.8 \pm 0.34 \mathrm{~b}$ \\
\hline Energy (kcal) & $441.0 \mathrm{a}$ & $417.0 \mathrm{~b}$ \\
\hline
\end{tabular}

${ }^{(1)}$ Means followed by different letters differ by the F-test, at $5 \%$ probability.
7064) extruded flour, and evaluated their sensory, nutritional, and functional properties. The chemical analyses indicated that both powdered formulates are also potential sources of fiber and proteins (Anvisa, 2012). Thus, sorghum flour is a potential ingredient to make more nutritious churros and other gluten-free products.

T-churro ('BRS 305') and TF-churro ('BR 501') showed significant differences for antioxidant activity (Table 3). The total phenolic contents of the 'BRS 305' (with tannin) and 'BR 501' (white grain, without tannin) flours were similar to those found by Awika et al. (2009) in tannin sorghum grains (16.5-29.6 mg GAE $\left.\mathrm{g}^{-1}\right)$, although they were lower than the total phenolic contents of the white tannin-free sorghum $(8.1 \mathrm{mg}$ GAE $\left.\mathrm{g}^{-1}\right)$. Despite the fact that they were extracted by the same method (acidified methanol), the white cultivars used in this work and by Awika et al. (2009) have genetic differences and were not cultivated in the same environmental conditions, which may have influenced the results found in both studies.

There was an effect of the cultivar (with BRS 305 or BR 501), processing type (raw, cooked, or fried), and the interaction between these two factors on the tannin contents, total anthocyanins, total phenols, and antioxidant activity. For all compounds and in all types of processing, the contents were significantly higher in

Table 3. Tannins, anthocyanins, total phenol contents and antioxidant activity [db] in flour and in the raw, cooked, and fried churros formulated with flour from the Sorghum bicolor cultivars BRS 305 (with tannin - T-churro) and BR 501 (tannin-free - TF-churro) ${ }^{(1)}$.

\begin{tabular}{|c|c|c|c|c|c|}
\hline Churros & Sample & $\begin{array}{c}\text { Tannins } \\
\left(\mathrm{mg} \mathrm{g}^{-1} \mathrm{CE}\right)^{(2)}\end{array}$ & $\begin{array}{l}\text { Anthocyanins } \\
\left(\mathrm{mg} \mathrm{g}^{-1} \mathrm{LE}\right)^{(3)}\end{array}$ & $\begin{array}{c}\text { Phenols } \\
\left(\mathrm{mg} \mathrm{g}^{-1} \mathrm{GAE}\right)^{(4)}\end{array}$ & $\begin{array}{c}\text { Antioxidant activity } \\
\left(\mu \mathrm{mol} \mathrm{g}{ }^{-1} \mathrm{TE}\right)^{(5)}\end{array}$ \\
\hline \multirow{6}{*}{$\begin{array}{l}\text { T-churro } \\
\text { (BRS 305) }\end{array}$} & Flour & 57.1 & 0.26 & 19.7 & 186.7 \\
\hline & Raw dough & $33.0 \mathrm{aA}$ & $0.27 \mathrm{aA}$ & $18.5 \mathrm{aA}$ & $215.7 \mathrm{aA}$ \\
\hline & Cooked dough & $15.7 \mathrm{bA}$ & $0.20 \mathrm{bA}$ & $12.0 \mathrm{bA}$ & $162.0 \mathrm{bA}$ \\
\hline & Fried dough & $12.2 \mathrm{cA}$ & $0.15 \mathrm{cA}$ & $9.9 \mathrm{cA}$ & $115.5 \mathrm{cA}$ \\
\hline & Retention (\%) & 37.0 & 55.5 & 53.6 & 56.6 \\
\hline & Losses $(\%)$ & 63.0 & 44.5 & 46.4 & 46.4 \\
\hline \multirow{6}{*}{$\begin{array}{l}\text { TF-churro } \\
\text { (BR 501) }\end{array}$} & Flour & 0.09 & 0.08 & 3.92 & 3.9 \\
\hline & Raw dough & nd & $0.10 \mathrm{aB}$ & $6.0 \mathrm{aB}$ & $9.8 \mathrm{aB}$ \\
\hline & Cooked dough & nd & $0.09 \mathrm{aB}$ & $3.9 \mathrm{bB}$ & $8.4 \mathrm{aB}$ \\
\hline & Fried dough & nd & $0.07 \mathrm{bB}$ & $2.6 \mathrm{cB}$ & $6.4 \mathrm{aB}$ \\
\hline & Retention (\%) & & 70.6 & 42.7 & 65.5 \\
\hline & Losses (\%) & & 29.4 & 57.3 & 34.5 \\
\hline
\end{tabular}

${ }^{(1)}$ Means followed by equal, capital letters, in each column between the churros from BRS 305 (T-churro) and BR 501 (TF-churro) cultivars, and by the equal, lowercase letter, among types of dough of each churro, do not differ by Tukey's test, at $5 \%$ probability. ${ }^{(2)} \mathrm{CE}$, catechin equivalent (vanillin- $\mathrm{HCl}$ method). ${ }^{(3)} \mathrm{LE}$, luteolinidin equivalent. ${ }^{(4)} \mathrm{GAE}$, gallic acid equivalent (FolinCiocalteu method). ${ }^{(5)} \mathrm{TE}$, trolox equivalent (ABTS method). Values \pm SD (standard deviation) reported for three separate replicates. 
T-churro than in TF-churro. The total phenol content of T-churro was about three times higher than that of TF-churro, while the antioxidant activity was about 20 times higher. This difference is probably due to the high content of condensed tannins present in 'BRS 305' and its absence in 'BR 501'. These compounds are widely recognized in the literature as highly antioxidative (Hagerman et al., 1998). Tannins are 15-30 times more effective than simple phenols in radical scavenging ability (Hagerman et al., 1998). The functional benefits of tannin are reported as being immunomodulatory, anticancer, antioxidant antiradical, anti-inflammatory, vasodilatory, cardioprotective, antithrombotic, and anti-UV actions ( $\mathrm{Wu}$ et al., 2012). the antioxidant activity, phenols, tannins, and anthocyanin contents were also found to be higher in a powdered drink mix with tannin-sorghum than in drink from the tanninfree sorghum (Queiroz et al., 2018). Therefore, tannin sorghum may be an attractive ingredient to make functional gluten-free products.

For raw, cooked, and fried samples within each sorghum cultivar, it was observed that in the T-churro ('BRS 305'), the contents of all bioactive compounds were reduced after cooking and after frying, finishing with the lowest contents in the product ready for consumption (losses between 44.5 and 63\%). In TF-churro ('BR 501'), the losses were less significant (losses between 29.4 and 57.3\%) and occurred only for the anthocyanin contents after frying, and for phenols after cooking and after frying. This fact may be attributed to the lower content of these compounds in the flour from 'BR 501' than flour from 'BRS 305'. These losses can be explained by the use of high temperatures in the wet heat (cooking) and frying that may have caused the thermal denaturation of these constituents, or may be attributed to changes or disruption of several structures, such as starch or protein which could interact with the phenolic compounds and interfere during the extraction (Domínguez Avila et al., 2017).

Our results corroborate the findings by Hithamani \& Srinivasan (2014), who reported an average loss of 50.9 and $42.9 \%$ of phenolic compounds, and 22 and $55 \%$ of tannin contents in sorghum after subjecting the cereal to wet cooking under pressure (103421 pascals, $15 \mathrm{~min}$ ) and open pan boiling (10 min), respectively. Nevertheless, it is essential to highlight that churros dough was subjected to two types of thermal processing: cooking and frying, and, despite that, the ready-to-eat products (fried) still showed more than $50 \%$ retention of anthocyanins, phenols, and antioxidant activity in T-churro ('BRS 305') and about, respectively, 70, 40, and $65 \%$ in TF-churro ('BR 501'). In this context, it is speculated whether the use of sorghum cultivars with high levels of bioactive compounds may allow, even after thermal processing, quite interesting levels of these compounds in the final product.

T-churro ('BR S305') showed the lowest retention of tannin content (37\%). According to Dlamini et al. (2007), the reduction of the antioxidant activity by sorghum processing with tannin can be attributed to a strong interaction of tannins with prolamins. The protein denaturation produced by the cooking process unfolds the native protein structure favoring the protein and tannin interactions.

\section{Conclusions}

1. Churros formulated with tannin and tannin-free sorghum (Sorghum bicolor) flours show a high sensory acceptability and purchase intention by tasters; the presence of tannin does not negatively affect the acceptance of the tannin sorghum product.

2. Churros manufactured with flour of the BR 501 and BRS 305 sorghum cultivars were considered fiber sources.

3. All phenolic compounds are higher in the raw, cooked, and fried tannin sorghum churros; however, the total phenol content of the churro made with 'BRS 305 ' sorghum flour is about three times higher than that of ones made with 'BR 501' sorghum flour, whereas the antioxidant activity is about 20 times higher.

4. The ready-to-eat product (fried) made with tannin sorghum flour from BRS 305 cultivar shows anthocyanins, phenols, and antioxidant capacity retention even after being processed by two types of thermal processing (cooking and frying).

5. Flour of whole grain sorghum shows a great potential to produce tasty and nutritious gluten-free foods.

\section{Acknowledgments}

To Fundação de Amparo à Pesquisa do Estado de Minas Gerais (Fapemig), to Conselho Nacional de Desenvolvimento Científico e Tecnológico (CNPq), and to Empresa Brasileira de Pesquisa Agropecuária (Embrapa), for financial support. 


\section{References}

ADIAMO, O.Q.; FAWALE, O.S.; OLAWOYE, B. Recent trends in the formulation of gluten-free sorghum products. Journal of Culinary Science \& Technology, v.16, p.311-325, 2018. DOI: https://doi.org/10.1080/15428052.2017.1388896.

ANUNCIAÇÃO, P.C.; CARDOSO, L. de M.; GOMES, J.V.P.; DELLA LUCIA, C.M.; CARVALHO, C.W.P.; GALDEANO, M.C.; QUEIROZ, V.A.V.; ALFENAS, R. de C.G.; MARTINO, H.S.D.; PINHEIRO-SANT'ANA, H.M. Comparing sorghum and wheat whole grain breakfast cereals: sensorial acceptance and bioactive compound content. Food Chemistry, v.221, p.984-989, 2017. DOI: https://doi.org/10.1016/j.foodchem.2016.11.065.

ANVISA. Agência Nacional de Vigilância Sanitária. Resolução RDC no 54, de 12 de novembro de 2012. Dispõe sobre o Regulamento Técnico sobre Informação Nutricional Complementar. 2012. Available at: <http://portal.anvisa.gov. br/wps/wcm/connect/630a98804d7065b981f1e1c116238c3b/ Resolucao+RDC+n.+54_2012>. Accessed on: Sep. 92020.

AOCS. American Oil Chemists' Society. Official methods and recommended practices of the AOCS. $5^{\text {th }}$ ed. Champaign, 2004. Official Method Am 5-04: rapid determination of oil/fat utilizing high temperature solvent extraction.

AWIKA, J.M.; ROONEY, L.W.; WANISKA, R.D. Anthocyanins from black sorghum and their antioxidant properties. Food Chemistry, v.90, p.293-301, 2004. DOI: https://doi.org/10.1016/j. foodchem.2004.03.058

AWIKA, J.M.; ROONEY, L.W.; WU, X.; PRIOR, R.L.; CISNEROS-ZEVALLOS, L. Screening methods to measure antioxidant activity of sorghum (Sorghum bicolor) and sorghum products. Journal of Agricultural and Food Chemistry, v.51, p.6657-6662, 2003. DOI: https://doi.org/10.1021/jf034790i.

AWIKA, J.M.; YANG, L.; BROWNING, J.D.; FARAJ, A. Comparative antioxidant, antiproliferative and phase II enzyme inducing potential of sorghum (Sorghum bicolor) varieties. Food Science and Technology, v.42, p.1041-1046, 2009. DOI: https://doi.org/10.1016/j.lwt.2009.02.003.

BRASIL. Conselho Nacional de Saúde. Resolução no 466, de 12 de dezembro de 2012. [Aprova as diretrizes e normas regulamentadoras de pesquisas envolvendo seres humanos]. Diário Oficial da União, 13 jun. 2013. Seção1, p.59-62. Available at: $\quad<$ https://pesquisa.in.gov.br/imprensa/jsp/visualiza/index. jsp?data $=13 / 06 / 2013 \&$ jornal $=1 \&$ pagina $=59 \&$ totalArquivos $=140>$. Accessed on: Dec. 12020.

CARDOSO, L. de M.; PINHEIRO, S.S.; MARTINO, H.S.D.; PINHEIRO-SANT'ANA, H.M. Sorghum (Sorghum bicolor L.): nutrients, bioactive compounds, and potential impact on human health. Critical Reviews in Food Science and Nutrition, v.57, p.372-390, 2017. DOI: https://doi.org/10.1080/10408398.2014.887 057.

CHÁVEZ, D.; ASCHERI, J.; MARTINS, A.; CARVALHO, C.; BERNARDO, C.; TELES, A. Sorghum, an alternative cereal for gluten-free product. Revista Chilena de Nutrición, v.45, p.169177, 2018. DOI: https://doi.org/10.4067/s0717-75182018000300169.
DLAMINI, N.R.; TAYLOR, J.R.N.; ROONEY, L.W. The effect of sorghum type and processing on the antioxidant properties of African sorghum-based foods. Food Chemistry, v.105, p.14121419, 2007. DOI: https://doi.org/10.1016/j.foodchem.2007.05.017.

DOMÍNGUEZ AVILA, J.A.; WALL MEDRANO, A.; RUIZ PARDO, C.A.; MONTALVO GONZÁLEZ, E.; GONZÁLEZ AGUILAR, G.A. Use of nonthermal technologies in the production of functional beverages from vegetable ingredients to preserve heat-labile phytochemicals. Journal of Food Processing and Preservation, v.42, e13506, 2017. DOI: https://doi.org/10.1111/ jfpp.13506.

FAO. Food and Agriculture Organization of the United Nations. Food energy - methods of analysis and conversion factors. Rome, 2003. (FAO. Food and Nutrition Paper, 77).

FERREIRA, D.F. Sisvar: a computer statistical analysis system. Ciência e Agrotecnologia, v.35, p.1039-1042, 2011. DOI: https://doi.org/10.1590/S1413-70542011000600001.

GOMENSORO, M.L. Pequeno dicionário de gastronomia. Rio de Janeiro: Objetiva, 1999.

GULARTE, M.A. Manual de análise sensorial de alimentos. Pelotas: UFPel, 2009.

HAGERMAN, A.E.; RIEDL, K.M.; JONES, G.A.; SOVIK, K.N.; RITCHARD, N.T.; HARTZFELD, P.W.; RIECHEL, T.L. High molecular weight plant polyphenolics (tannins) as biological antioxidants. Journal of Agricultural and Food Chemistry, v.46, p.1887-1892, 1998. DOI: https://doi.org/10.1021/jf970975b.

HITHAMANI, G.; SRINIVASAN, K. Bioaccessibility of polyphenols from wheat (Triticum aestivum), sorghum (Sorghum bicolor), green gram (Vigna radiata), and chickpea (Cicer arietinum) as influenced by domestic food processing. Journal of Agricultural and Food Chemistry, v.62, p.11170-11179, 2014. DOI: https://doi.org/10.1021/jf503450u.

HORWITZ, W. (Ed.). Official Methods of Analysis of AOAC International. $17^{\text {th }}$ ed. Gaithersburg: AOAC International, 2000. Official Method 936.03

KALUZA, W.Z.; MCGRATH, R.M.; ROBERTS, T.C.; SCHROEDER, H.H. Separation of phenolics of Sorghum bicolor (L.) Moench grain. Journal of Agricultural and Food Chemistry, v.28, p.1191-1196, 1980. DOI: https://doi.org/10.1021/ jf60232a039.

LESSCHAEVE, I.; NOBLE, A.C. Polyphenols: factors influencing their sensory properties and their effects on food and beverage preferences. American Journal of Clinical Nutrition, v.81, p.330S-335S, 2005. Suppl. DOI: https://doi.org/10.1093/ ajen/81.1.330S.

LOUCOS POR CHURROS. Tabela nutricional: galetas sem cobertura. Available at: $<$ http://loucosporchurros.com.br/tabelanutricional>. Accessed on: July 162018.

LUNA PIZARRO, P.; ALMEIDA, E.L.; COELHO, A.S.; SAMMÁN, N.C.; HUBINGER, M.D.; CHANG, Y.K. Functional bread with n-3 alpha linolenic acid from whole chia (Salvia hispanica L.) flour. Journal of Food Science and Technology, v.52, p.4475-4482, 2015. DOI: https://doi.org/10.1007/s13197-0141477-5. 
MARTINO, H.S.D.; TOMAZ, P.A.; MORAES, E.A.; CONCEIÇÃO, L.S. da; OLIVEIRA, D. da S.; QUEIROZ, V.A.V.; RODRIGUES, J.A.S.; PIROZI, M.R.; PINHEIRO SANT'ANA, H.M.; RIBEIRO, S.M.R. Chemical characterization and size distribution of sorghum genotypes for human consumption. Revista do Instituto Adolfo Lutz, v.71, p.337-344, 2012.

PRICE, M.L.; VAN SCOYOC, S.; BUTLER, L.G. A critical evaluation of the vanillin reaction as an assay for tannin in sorghum grain. Journal of Agricultural and Food Chemistry, v.26, p.1214-1218, 1978. DOI: https://doi.org/10.1021/jf60219a031.

QUEIROZ, V.A.V.; AGUIAR, A. da S.; MENEZES, C.B. de; CARVALHO, C.W.P. de; PAIVA, C.L.; FONSECA, P.C.; CONCEIÇÃO, R.R.P. da. A low calorie and nutritive sorghum powdered drink mix: influence of tannin on the sensorial and functional properties. Journal of Cereal Science, v.79, p.43-49, 2018. DOI: https://doi.org/10.1016/j.jcs.2017.10.001.

QUEIROZ, V.A.V.; CARNEIRO, H.L.; DELIZA, R.; RODRIGUES, J.A.S.; VASCONCELLOS, J.H. de; TARDIN, F.D.; QUEIROZ, L.R. Genótipos de sorgo para produção de barra de cereais. Pesquisa Agropecuária Brasileira, v.47, p.287-293, 2012. DOI: https://doi.org/10.1590/S0100-204X2012000200018.

QUEIROZ, V.A.V.; SILVA, C.S. da; MENEZES, C.B. de; SCHAFFERT, R.E.; GUIMARÃES, F.F.M.; GUIMARÃES, L.J.M.; GUIMARÃES, P.E. de O.; TARDIN, F.D. Nutritional composition of sorghum [sorghum bicolor (L.) Moench] genotypes cultivated without and with water stress. Journal of Cereal
Science, v.65, p.103-111, 2015. DOI: https://doi.org/10.1016/j. jcs.2015.06.018.

SALAZAR-LÓPEZ, N.J.; GONZÁLEZ-AGUILAR, G.; ROUZAUD-SÁNDEZ, O.; ROBLES-SÁNCHEZ, M. Technologies applied to sorghum (Sorghum bicolor L. Moench): changes in phenolic compounds and antioxidant capacity. Food Science and Technology, v.38, p.369-382, 2018. DOI: https://doi.org/10.1590/fst.16017.

SOARES, R.R.A.; VASCONCELOS, C.M.; OLIVEIRA, M.V. de; MININ, V.P.R.; QUEIROZ, V.A.V.; BARROS, F. Starch digestibility and sensory acceptance of gluten-free foods prepared with tannin sorghum flour. Pesquisa Agropecuária Brasileira, v.54, e01205, 2019. DOI: https://doi.org/10.1590/S1678-3921. pab2019.v54.01205.

VILLANUEVA, N.D.M.; PETENATE, A.J.; SILVA, M.A.A.P. da. Performance of the hybrid hedonic scale as compared to the traditional hedonic, self-adjusting and ranking scales. Food Quality and Preference, v.16, p.691-703, 2005. DOI: https://doi.org/10.1016/j.foodqual.2005.03.013.

WU, Y.; LI, X.; XIANG, W.; ZHU, C.; LIN, Z.; WU, Y.; LI, J.; PANDRAVADA, S.; RIDDER, D.D.; BAI, G.; WANG, M.L.; TRICK, H.N.; BEAN, S.R.; TUINSTRA, M.R.; TESSO, T.T.; YU, J. Presence of tannins in sorghum grains is conditioned by different natural alleles of Tannin1. Proceedings of the National Academy of Sciences of the United States of America, v.109, p.10281-10286, 2012. DOI: https://doi.org/10.1073/ pnas. 1201700109. 